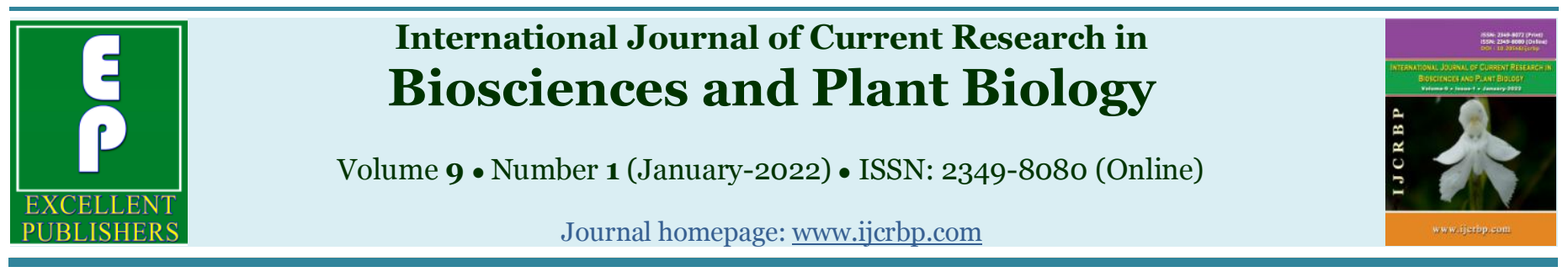

Original Research Article

doi: https://doi.org/10.20546/ijcrbp.2022.901.002

\title{
Effect of two fungal fertilizers (Psathyrella tuberculata and Daldinia concentrica) on the production parameters of tomato (Solanum lycopersicum L.) in Daloa (Centre-West, Côte d'Ivoire)
}

\author{
N'Douba Amako Pauline ${ }^{(1}{ }^{*}$, Groga Noel $^{1}$, Tra Bi Crolaud Sylvain ${ }^{1}$, \\ N'Da Diane Sara-Elisabeth Francine $^{1}$, Douira Allal ${ }^{2}$, Ayolié Koutoua ${ }^{1}$
}

\author{
${ }^{1}$ Laboratoire de l'Amélioration de la Production Agricole, UFR Agroforesterie, Université Jean Lorougnon Guédé, \\ BP 150 Daloa, Côte d'Ivoire \\ ${ }^{2}$ Laboratoire de Botanique, Biotechnologie et Protection des plantes, Faculté des sciences Kenitra, \\ Université Ibn Tofail Kenitra, BP 133 Kenitra, Maroc \\ *Corresponding author; e-mail: ndoubap@yahoo.fr
}

\begin{abstract}
Article Info
Keywords:

Daldinia concentrica

Fertilizers

Fungi

Psathyrella tuberculata

Tomato

\section{Abstract}

In the search for biological substances for sustainable agriculture, the present study proposes to use fungal biofertilizers to improve the production of tomato crop. Thus, two species of dried superior fungi (Psathyrella tuberculata and Daldinia concentrica) were milled for use as soil fertilizer. Psathyrella tuberculata, Daldinia concentrica and a combination of $P$. tuberculata $+D$. concentrica were used as organic fertilizer for tomato plants grown from COBRA 26. The effect of these three fertilizers was compared with NPK 10-18-18 and the control. The results showed that the fungal fertilizers contributed to the improvement of tomato production. The highest values for the parameter number of fruits were obtained with the first group consisting of plots that received PSTU (2.42), DACO (2.75), NPK (2.75), PSTU+ DACO (3.00) and the lowest value on the plot TEMOIN (0.41). The combination of PSTU+DACO (3.00) gave the statistically higher values than the other fertilizers. The highest yield was recorded on the plots enriched with PSTU+DACO (6.67 t/ha). From the 30th DAR onwards, plants from plots fertilized with DACO, PSTU+DACO and PSTU started to flower. From 37 to 44 days, the plots with the highest number of flowering plants were those treated with PSTU (28 plants).
\end{abstract}

- Received: 12 November 2021 • Revised: 8 December 2021 • Accepted: 27 December 2021 • Published Online: 6 January 2022

\section{Introduction}

Tomato is one of the most consumed vegetables (FAO, 2012) and its cultivation is the most widespread throughout the world (Shankara, 2005). It is a source of vitamins (C, B6, B12, D) as well as an important cash crop for farmers. According to FAO (2012), it occupies the first place in vegetable production after potato. In 2009 , the world production of tomatoes amounted to over 141 million tons.

In Africa, tomato is the most cultivated vegetable 
species as it is used in the composition of many traditional dishes (Abidi, 2016). Vegetable gardening is an activity that contributes to the fight against poverty and the improvement of food security because it creates many jobs in rural areas during the dry season and generates income for those responsible for marketing (Loumedjinon et al., 2021a). In Côte d'Ivoire, despite an annual production that fluctuates between 22,000 and 35,000 tons (Sangaré et al., 2009), demand is still high. Indeed, tomato needs are estimated at more than 100,000 tons for the Ivorian population (Groga et al., 2018). This low yield is due to high disease pressure, low soil fertility and post-harvest storage (Adamou et al., 2017).

Also the overexploitation of land which results in the depletion of agricultural soils of essential nutrients, necessary for plant growth and productivity. Thus, chemical fertilizer amendments are essential for better yields (Baligar et al., 2001). Climatic hazards have adverse effects on soil fertility. To this end, techniques such as the use of biofertilisers are indicated in crops gardening (Loumedjinon, 2021b). The use of fungi (Psathyrella tuberculata and Daldinia concentrica) is presented as an alternative to ecological agriculture in order to avoid environmental pollution. In view of these aspects, a fundamental question remains: how to increase tomato production while improving agricultural soil fertility and preserving the quality of these fruits? This study was conducted to evaluate the effect of fungal biofertilizers $P$. tuberculata and $D$. concentrica on tomato productivity. The objective of this work is to optimize tomato production through the use of fungal biofertilizers.

\section{Materials and methods}

\section{Study site}

The trial was conducted at the experimental site of the Jean Lorougnon Guédé University in Daloa (Centre West, Côte d'Ivoire). Daloa is a forest area with a transitional humid tropical climate. It is characterized by two dry seasons from October to March and two rainy seasons with two maxima, one in June and the other in September (Koffie and Kra, 2013). The temperature ranges from $24.65^{\circ} \mathrm{C}$ to $27.75^{\circ} \mathrm{C}$ on average (Ligban et al., 2009). Rainfall (1,200 and 1,600 millimetres per year) is an asset for agriculture and especially for the development of perennial crops such as coffee and cocoa. Rainfall is distributed throughout the year with a maximum in June and July and a minimum from December to March. The soil is ferralitic of granitic origin of medium to low denaturation (Koffie and Kra, 2013).

\section{Material}

\section{Plant and fungal material}

The plant material consists of seedlings of the Cobra 26 variety. They were chosen for their high germination rate, purity and also for their resistance to diseases. As for the fungal material, it is composed of two species of dry fungi of Psathyrella tuberculata (Fig. 1A) and Daldinia concentrica (Fig. 1B). These fungal species were chosen for some of their potentialities such as the antimicrobial elements they contain and their high mineral content.

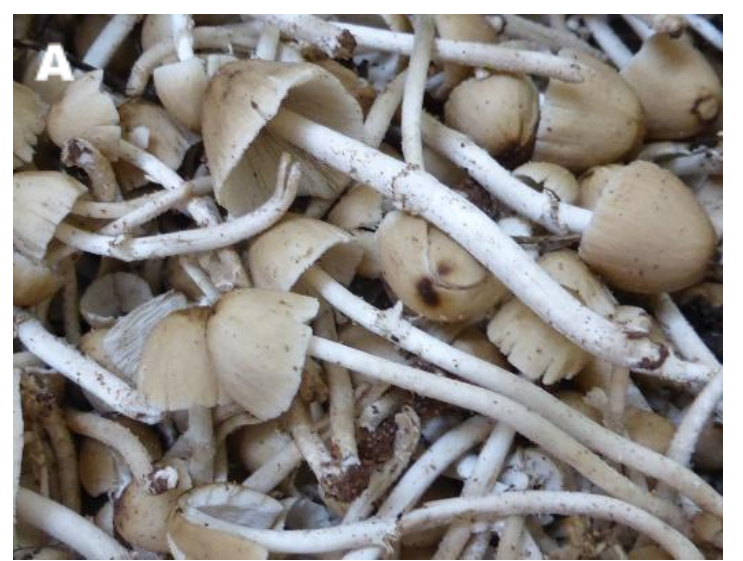

Fig. 1: Fungal species, A: Carpophore of P. tuberculata in fresh state; B: Carpophore of D. concentrica

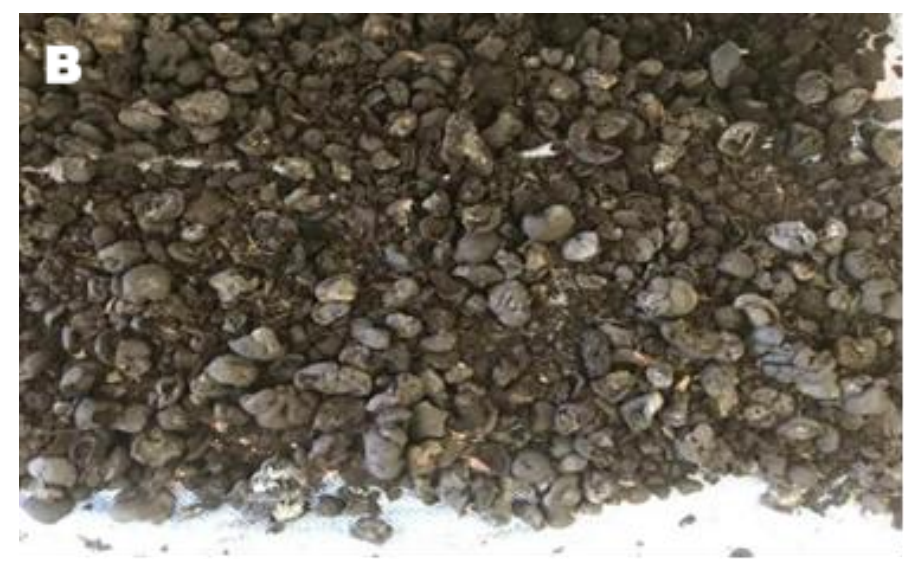

in the fresh state. 


\section{Chemical material}

The chemical fertilizer used, was the mineral fertilizer NPK 10-18-18. This is the most used fertilizer by farmers in tomato crop (ANADER, 2015). Mancozeb $800 \mathrm{~g} / \mathrm{kg}$, a contact fungicide with broad spectrum of action was also used to protect the crop from fungal diseases.

\section{Methods}

\section{Preparation of the mushroom powder}

After sampling, the harvested mushrooms were dried in the shade for two (02) weeks to reduce the moisture content. The mushroom powder was obtained in a RETSCH type grinder.

\section{Setting up the nursery}

The tomato nursery was carried out on a $4 \mathrm{~m}^{2}$ surface $(2 \times 2 \mathrm{~m})$ and $5 \mathrm{~cm}$ high bed. After sowing, the bed was covered with a black polypropylene tarpaulin to protect it and accelerate the lifting of seed dormancy. Three days after sowing, the plastic was removed, a mosquito net was placed to protect the nursery from insect pests and a shade canopy was placed over the nursery. Watering was done twice a day for 21 days.

Transplanting of the seedlings was done on $22^{\text {éme }}$ days after sowing on a completely randomized Fisher block design with two replications per treatment (Fig. 2). A plot of $(16 \mathrm{~m} \times 13 \mathrm{~m})$ consisting of two sub-blocks spaced $2 \mathrm{~m}$ apart was set up. Each block (16 m x $7.5 \mathrm{~m})$ consisted of five elementary plots spaced $1 \mathrm{~m}$ apart. Each elementary plot $(1 \mathrm{~m} \times 5 \mathrm{~m})$ consisted of 20 seed points. The seedling points were spaced $0.8 \mathrm{~m}$ apart between the lines and $0.5 \mathrm{~m}$ apart on the line. Maintenance of the nursery was done every two weeks to eliminate weeds. Mancozeb $16.64 \mathrm{~g}$ was applied every two weeks.

\section{Fertilization of the plot}

Fertilization was done with fungal biofertilizers ( $P$. tuberculata and D. concentrica), the combination of these two fungal species and the mineral fertilizer NPK 10-18-18. The application was done on all the plots at a rate of $200 \mathrm{~kg} / \mathrm{ha}$ for PSTU and DACO, $200 \mathrm{~kg} / \mathrm{ha}$ for PSTU+DACO and $48 \mathrm{~kg} / \mathrm{ha}$ for NPK. NPK (10-18-18) was used at a rate of $80 \mathrm{~g}$ per bed in three applications.
The first application was made two weeks after transplanting at a rate of $4 \mathrm{~g}$ per plant. The three applications were spaced two weeks apart. All applications were made at $2 \mathrm{~cm}$ around the plants.

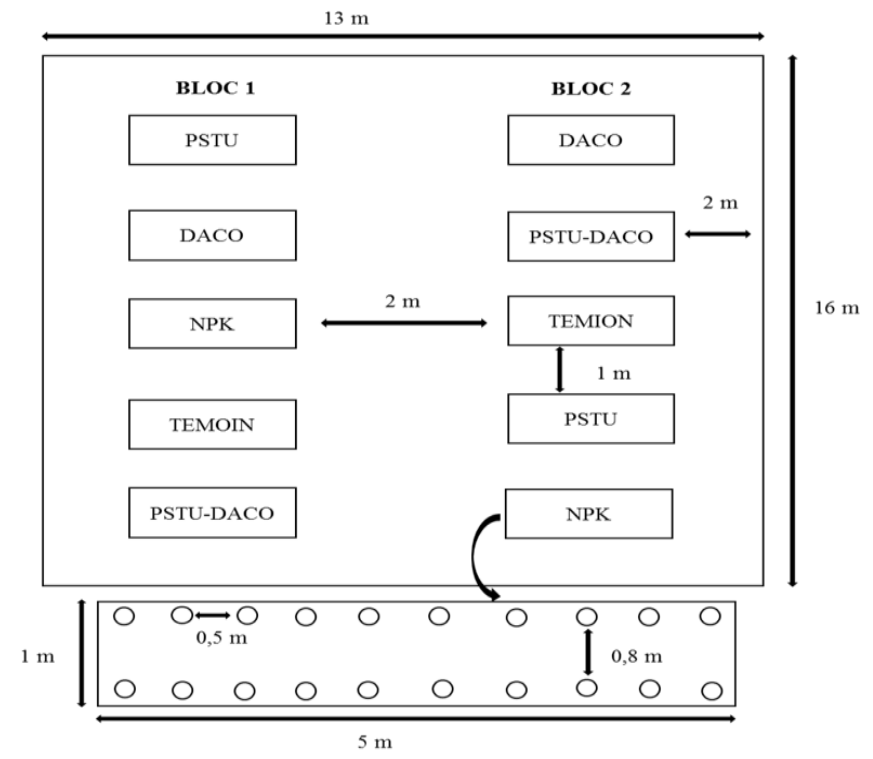

Fig. 2: Experimental setup.

\section{Data collection and analysis}

Three weeks after transplanting (23 days after transplanting), the flowering time of each plant and the number of flower clusters were recorded. The number of fruits per plant was counted after harvest and the production yield from the mass of fruits per plate was calculated. The production parameters of time to flowering were subjected to analysis of variance (ANOVA 1). Means were grouped using Fisher's LSD test at the 5\% threshold. All analyses were performed using STATISTICA Version 7.1 software.

\section{Results}

\section{Flowering time}

The action of fertilizers on the flowering of tomato plants varied according to time (days), 11-50 ( $D$. concentrica), 10-54 (P. tuberculata) and 13-50 (D. concentrica $+P$. tuberculata) (Fig. 3). Indeed, 23 days after transplanting (DAR), only the plants in plots treated with PSTU (15) and NPK (11) showed the first flowering. Of the two treatments, the NPK-treated plots had a high number of flowering plants (11 plants). 
From $30^{\text {th }}$ JAR the plants of the plots fertilized with DACO, PSTU +DACO and PSTU started to flower. A large number of plants flowered on the plots treated with PSTU (15 plants), followed by NPK (13 plants) and DACO (10 plants). From 37 to 44 DAR, the plots enriched with $P$. tuberculata had the highest number of flowers with respectively 20 and 28 plants on the plots enriched with PSTU; 17 and 25 plants for those treated with DACO. Finally, 15 and 26 plants for the plots fertilized with PSTU+DACO.

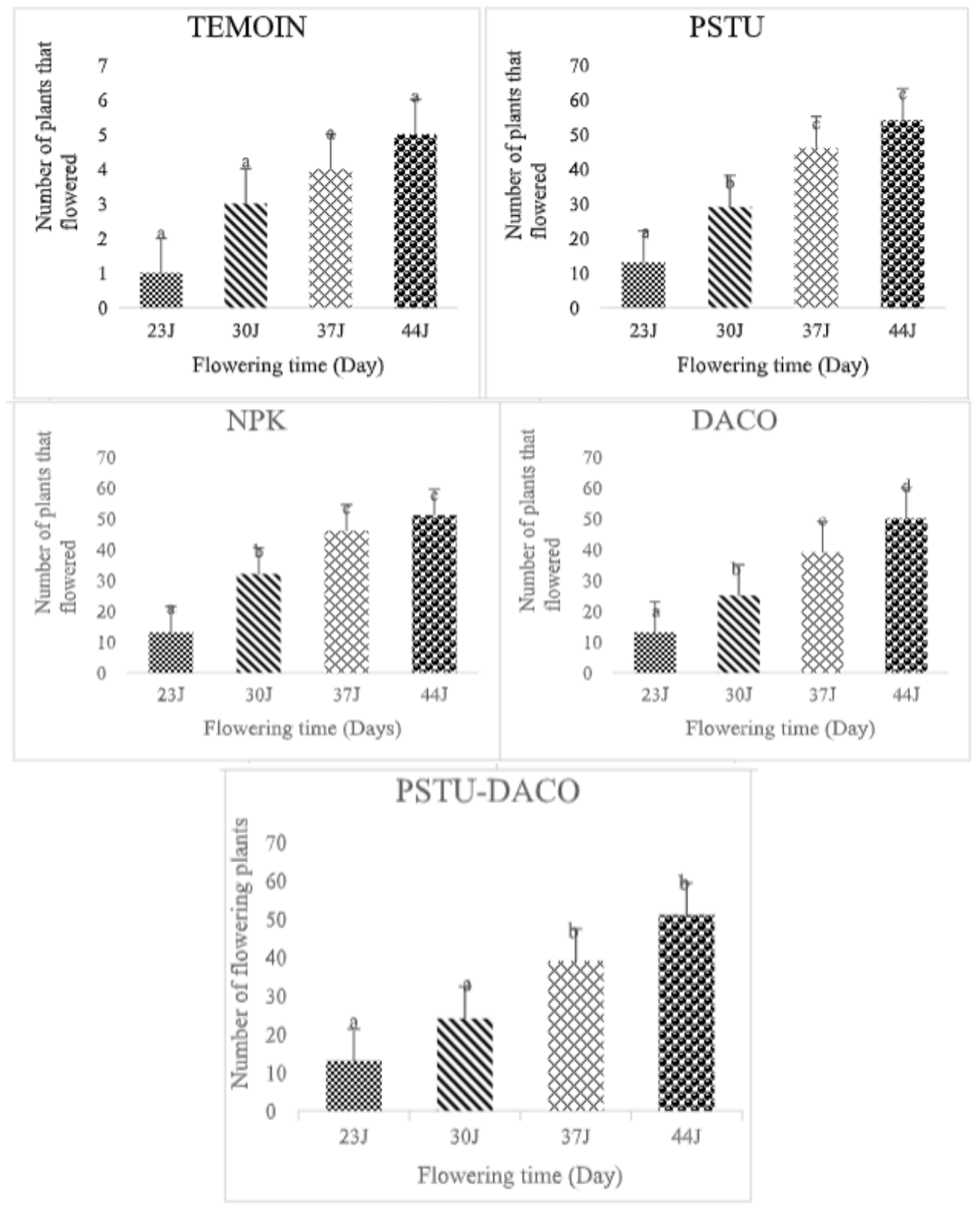

Fig. 3: Time of flower appearance according to treatments.

\section{Number of fruits per plant}

Overall, there was a clear variation in the number of fruits by treatment $(p=0.0013)$ on the number of fruits of the plants (Fig. 4). Mean values ranged from 0.41 on the TEMOIN plot to 3.00 on the plots enriched with PSTU-DACO. Two homogeneous groups were obtained. The data were subjected to a one-way analysis of variance (ANOVA 1) and completed by Fisher's LSD test at the 5\% threshold. Two groups were found. The highest values were obtained with the first group consisting of plots that received PSTU (2.42), DACO (2.75), NPK (2.75), PSTU+DACO (3.00) and the lowest value on the TEMOIN plot $(0.41)$. 


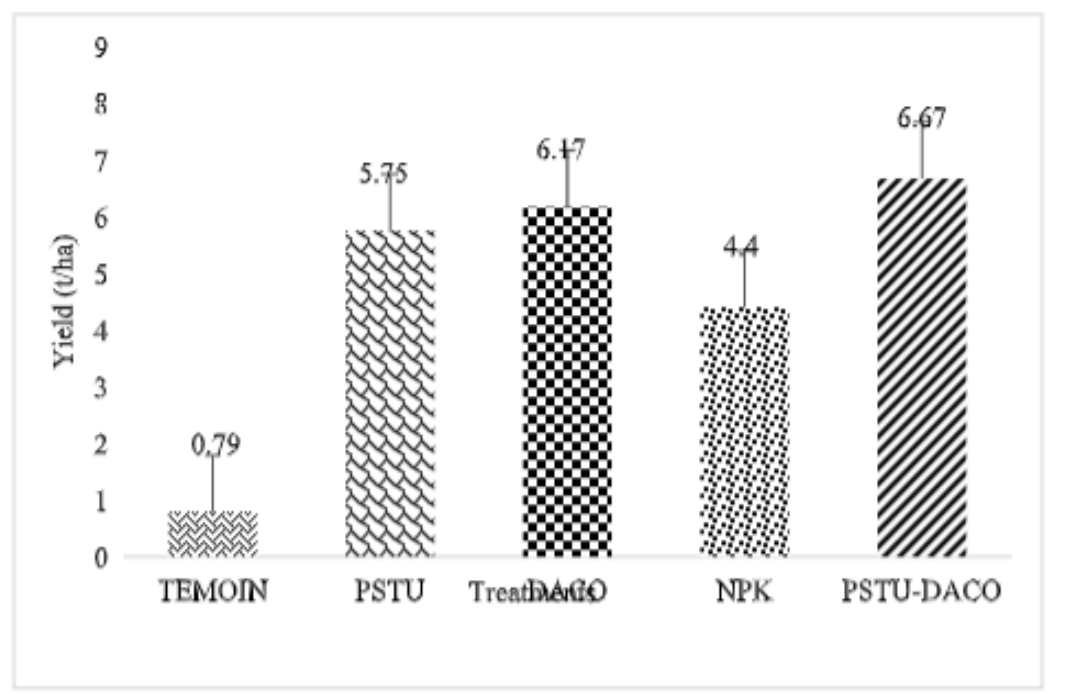

Fig. 4: Effect of treatments on fruit weight. PSTU: Psathyrella tuberculata; DACO: Daldinia concentrica; PSTU+ DACO: Psathyrella tuberculata + Daldinia concentrica; TEMOIN: control: plots without fertilizer application, NPK: chemical fertilizer. Data were subjected to one-criterion analysis of variance (ANOVA 1) using STATISTICA 7.1 software. The analysis of variance was completed by Fisher's LSD test at the 5\% threshold.

\section{Efficiency according to the type of treatment}

The yield of tomato plants differed according to treatment (Fig. 5). Transplanted plants on plots treated with the fungal fertilizers PSTU, DACO and PSTU+DACO were significantly higher than the control and the NPK-treated plot. The highest value was recorded on the plots enriched with PSTU+DACO (6.67 t/ha). They were followed by the plots fertilized with DACO and PSTU with yields of $6.17 \mathrm{t} / \mathrm{ha}$ and $5.75 \mathrm{t} / \mathrm{ha}$ respectively. On the other hand, the lowest yield value was recorded on the control plots $(0.79 \mathrm{t} / \mathrm{ha})$.

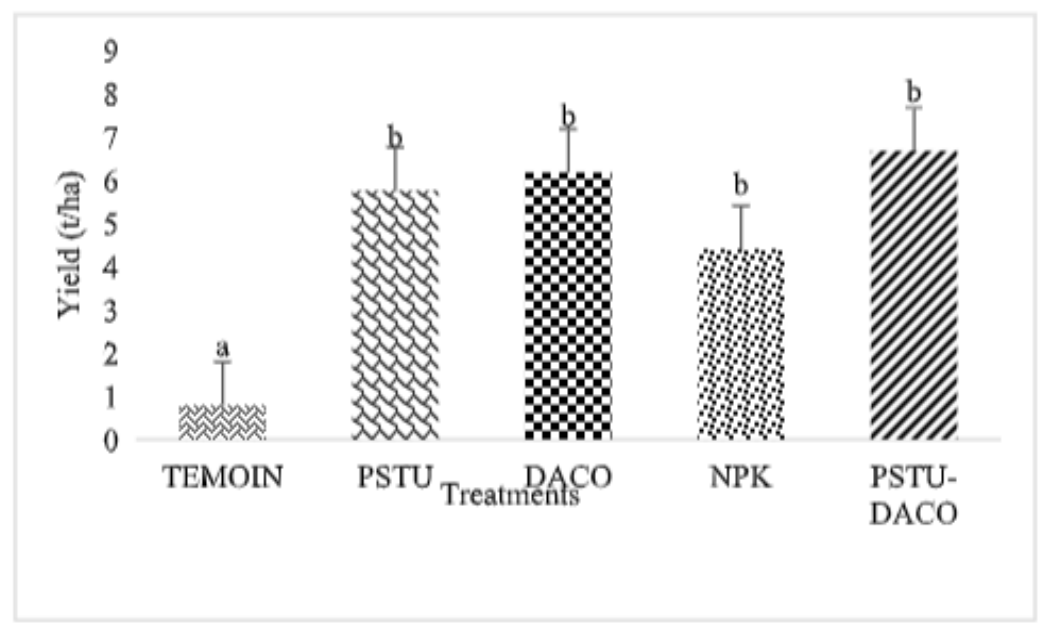

Fig. 5: Effect of treatments on tomato yield. PSTU: P. tuberculata; DACO: $D$. concentrica; PSTU+ DACO: $P$. tuberculata $+D$. concentrica; TEMOIN: control: plots without fertilizer application, NPK: chemical fertilizer. Data were subjected to one-criterion analysis of variance (ANOVA 1) using STATISTICA 7.1 software. The analysis of variance was completed by Fisher's LSD test at the 5\% threshold. 


\section{Discussion}

The high values of the number of flowering plants were respectively recorded on the plots fertilized with PSTU (1.36, 2.63, 4.18 and 4.90), DACO (1.36, 2.27, 3.54 and 4.54), NPK (1.27; 2.90; 4.18 and 4.63) and PSTU+DACO $(1.27 ; 2.18 ; 3.54$ and 4.63$)$ and the low values on the control plots $(0.18 ; 0.27 ; 0.36$ and 0.45$)$. Kotaix et al. (2013) in their work in Bimbresso and Bouaflé, showed that the organic fertilizer Dragon 1, through the doses 3.75 and $5 \mathrm{~L} /$ ha allowed the plants to have a higher rate of flowering than the doses 300 and $600 \mathrm{Kg} / \mathrm{ha}$ of mineral fertilizer. These results obtained, may be due to the mineral elements contained in the fungal fertilizers, especially phosphorus, which is a stimulator of flowering (Kotaix, 2013). These results corroborate those of Christian et al. (2005), which state that phosphorus is a nutrient that stimulates flowering precocity.

Fungal biofertilizers ( $P$. tuberculata, D. concentrica) and the combination of PSTU+DACO) applied to tomato plants resulted in good yields. The number of fruits of the control tomato plants was statistically lower as the average was (4.75). However, PSTU (2.42), DACO (2.75), NPK (2.75) and PSTU+DACO (3.00) recorded statistically significant values. Moreover, the plots fertilized with the combination of PSTU+DACO, $D$. concentrica and $P$. tuberculata resulted in tomato plants having larger fruit sizes and higher yields compared to the control and NPK treated plants. This could be explained by the fact that the fungi ensure a better assimilation of nutrients from the environment. In the same sense, Konfé et al (2019) showed that turbobio and mineral fertilizer induced more flower, fruit and biomass (aerial and root) formation compared to the control.

Indeed, the work of Rudresh et al. (2005) and Gravel et al. (2007) showed that species of the genus Trichoderma influence plant growth by synthesizing phytohormones such as indole 3 -acetic acid (IAA) and by improving the bioavailability of soil nutrients through solubilization of phosphate and other nutrients such as iron, copper, manganese and zinc. The use of CMA fungi of the genus Glomus contributed to the improvement of crops of three tomato varieties by effectively colonizing the roots of these plants (Banito, 2015). These results could also be explained by the fact that fungal biofertilizers improve soil fertility over time. Our results are confirmed by the work of Zaoui and
Brun (2011), which showed that biofertilizers allow a net increase in the efficiency of fertilization of difficultto-work soils. According to FAO (2003), the combination of organic and mineral fertilizers creates the best production conditions for crops. Noha and Mona (2020) have shown that mycorrhizal fungi represent a promising resource for improving both sustainable food production and plant nutritional requirements.

\section{Conclusions}

The study on the improvement of tomato production aimed at evaluating the production through the use of fungal biofertilizers ( $P$. tuberculata and $D$. concentrica). It is part of the dynamics of sustainable improvement of food and vegetable crop productivity through environmentally friendly practices. The results showed that fungal fertilizers promote good growth. Regarding production parameters, $P$. tuberculata and NPK had the same flowering time of 23 days after transplanting compared to other treatments. Regarding flowering, mass and number of fruits per plant, the fungal fertilizers had the highest average values of the PSTU+DACO combination. It is also evident from this study that fungi gave high yield compared to chemical fertilization with NPK. Under experimental conditions, the use of $P$. tuberculata and $D$. concentrica as organic amendments provided a necessary source of nutrients for the tomato plant. Thus, these fungal biofertilizers could be an alternative for the improvement of food and vegetable crops and agricultural soil fertility.

\section{Conflict of interest statement}

Authors declare that they have no conflict of interest.

\section{References}

Adamou, H., Garba, M., Mairo, M., Adamou, B., Oumarou, S., Kimba, A., 2017. Geographical distribution of the tomato borer, Tuta absoluta Meyrick (Lepidoptera: Gelechiidae) in Niger. Scholars Acad. J. Biosci., 5(2): 108-113.

Anader, 2015. Document de formation des étudiants sur l'itinéraire technique des cultures maraichère. Agence Nationale d'Appui au Développement Rural zone Daloa, 48p.

Baligar, V.C., Fageria, N.K., He, Z.L., 2001. Nutrient use efficiency in plants. Commun. Soil Sci. Plant Anal., 32: 921-950. 
Banito, A., Banla, E. M., Ayisah, D. K., Sogbedji, J. M., 2015. Efficacité des champignons mycorhiziens contre les nématodes parasites de la tomate au Togo. J. Appl. Biosci., 89: 8256-8262.

Abidi, L., Snoussi, S.A., Bradea, M.S., 2016. Effet d'un bio fertilisant sur la qualité technologique et nutritionnelle de deux variétés de tomate cultivées sous serre. Rev. Agrobiol., 16: 101-104.

FAO (Food and Agricultural Organization), 2003. Les engrais et leur application. Brochure, 4è Edn. 5p.

FAO (Food and Agricultural Organization), 2012. Techniques de production de semences de tomate au Sénégal. Radhort-Publication, 22p.

Guédé, B., 2009. Le Partenaire. Bulletin de liaison de l'Anader, $\mathrm{N}^{\circ} 14,12 \mathrm{p}$.

Gravel, V., Antoun, H., Tweddell, J.R., 2007. Growth stimulation and fruit yield improvement of green house tomato plants by inoculation with Pseudomonas putida or Trichoderma atroviride: Possible role of indole acetic acid (IAA). Soil Biol. Biochem., 39: 1968-1977.

Groga, N., Diomande, M., Beugre, G.A.M., Ouattara, Y., Akaffou, D.S., 2018. Etude comparative de la qualité de la symbiose (Anabaena azollae, Azolla caroliniana), du compost et du NPK sur la croissance végétative et le rendement de la tomate (Lycopersicon esculentum mill. Solanacée) à Daloa (Côte d'Ivoire). J. Appl. Biosci., 129: 13004- 13014.

Koffie, B.C.Y., Kra, K.S., 2013. La région du HautSassandra dans la distribution des produits vivriers agricoles en Côte d'Ivoire. Rev. Géogr. Trop. d'Environ., 2: 95-103.

Konfe, Z., Zonou, B., Hien, E., 2019. Influence d'intrants innovants sur les propriétés du sol et la production de tomate (Solanum lycopersicum L.) et d'aubergine (Solanum melongena L.) sur un sol ferrugineux tropical en zone soudano-sahélienne au Burkina Faso. Int. J. Biol. Chem. Sci., 13(4): 21292146.

Kotaix, A.J.A., Angui, P.T.K., Pierre, C.Z.K., Diby, N.L., Dao, D., Bonfoh, B., 2013. Effet de l'engrais organique liquide «Dragon sur le developpement de la tomate au sud et au centre-Ouest de la Côte
d'Ivoire. Agron. Afr., 25(1): 37-52.

Ligban, R., Gone, L.D., Kamagate, B., Saley M. B., Biemi, J., 2009. Processus hydrogéochimique et origine des sources naturelles dans le degré carré de Daloa (Centre-Ouest de la Côte d'Ivoire). Int. J. Biol. Chem. Sci., 3(1): 38- 47.

Loumedjinon, E. V. S., Ayeni, G. A., Kegnide, E. R., Agani, F. O., Yabi, A. J., 2021a. Typologie des systèmes de production de tomate (Lycopersicon esculentum Mill.) au Sud du Benin. Rev. Afr. d'Environ. d'Agric., 4(2): 51-59.

Loumedjinon, E.V.S., Ayeni, G.A., Issaka, K., Agani F. O., Yabi, A.J., 2021b. Déterminants de l'adoption du compost à base de la jacinthe d'eau par les producteurs de tomate au Sud Bénin. Afr. Sci. 18(5): 52-65.

Noha, M. A., Mona, M. El-S., 2020. The impact of inoculation with arbuscular mycorrhizal fungi on tomato tolerance to salt stress and nutrients uptake in sandy soil. J. Agric. Chem. Biotechnol., 11(3): 63-70.

N'zi, J.C., Kouamé, C., Assanvo, S.P.N., Fondio L., Djidji, A.H., Sangare, A., 2010. Evolution des populations de Bemisia tabaci Genn selon les variétés de tomates (Solanum lycopersicum L.) au centre de la Côte d'ivoire. Sci. Nature, 7(1): 31-40.

Rudresh, D.L., Shivaprakash, M. K., Prasad, R. D., 2005. Tricalcium phosphate solubilizing abilities of Trichoderma spp. in relation to $\mathrm{P}$ uptake and growth and yield parameters of chickpea (Cicer arietinum L.). Can. J. Microbiol., 51: 217-222.

Sangaré, A., Koffi, E., Akamou, F., Fall, C.A., 2009. État des ressources phylogénétiques pour l'alimentation et l'agriculture. Ministère de l'agriculture, Abidjan, République de Côte d'Ivoire, Second rapport, 65p.

Shankara, N., Joep, V.L.D.J., Marja, D.G., Martin, H., Barbara, V., 2005. La culture de la tomate production, transformation et commercialisation. 105p.

Zaoui, E., Brun, G., 2011. Efficience de la fertilisation: nouveau défi pour l'agriculture moderne. Revue professionnelle des filières fruits et legumes: Agriculture du Maghreb, $\mathrm{n}^{\circ}$ 51, 139p.

\section{How to cite this article:}

N'Douba, A. P., Groga, N., Tra Bi Crolaud, S., N'Da Diane, S.-El. F., Douira, A., Ayolié, K., 2022. Effect of two fungal fertilizers (Psathyrella tuberculata and Daldinia concentrica) on the production parameters of tomato (Solanum lycopersicum L.) in Daloa (Centre-West, Côte d'Ivoire). Int. J. Curr. Res. Biosci. Plant Biol., 9(1): 12-18. doi: https://doi.org/10.20546/ijcrbp.2022.901.002 